\title{
ANTIOXIDANT AND ANTICANCER ACTIVITY OF EXTRACT AND FRACTIONS OBTAINED FROM DIOSPYROS MELANOXYLON ROXB. LEAVES AND CORRELATION WITH THEIR POLYPHENOLIC PROFILES
}

\author{
MD. HARUN AL RASHID ${ }^{1 *}$, DEEPAK BHARADWAJ P. V. P. ${ }^{2}$, SAYANI MAJUMDER ${ }^{1}$, VIVEKANANDA MANDAL ${ }^{3}$, \\ MAHADEB PAL ${ }^{2}$, SUBHASH CHANDRA MANDAL ${ }^{1}$, RAJARAJAN AMIRTHALINGAM THANDAVARAYAN ${ }^{4}$
}

1Pharmacognosy and Phytotherapy Research Laboratory, Division of Pharmacognosy, Department of Pharmaceutical Technology, Jadavpur University, Kolkata 700032, India, ${ }^{2}$ Division of Molecular Medicine, Bose Institute, Kolkata 700054, India, ${ }^{3}$ Institute of Pharmacy, Guru Ghasidas Central University, Bilaspur 495009, India, ${ }^{4}$ Department of Cardiovascular Sciences, Center for Cardiovascular Regeneration, Houston Methodist Research Institute, TX 77030, USA

Email: mdharunalrashid15@gmail.com

Received: 04 Jul 2017 Revised and Accepted: 26 Sep 2018

\section{ABSTRACT}

Objective: The current study evaluates the antioxidant and cytotoxic prospective of the leaves from Diospyros melanoxylon Roxb. (D. melanoxylon).

Methods: Qualitative phytochemical analysis of the samples from D. melanoxylon was carried out for the detection of secondary metabolites. Total content of flavonoids, phenolics, triterpenoids, and tannins in D. melanoxylon was evaluated using colorimetric assay. Qualitative analysis of polyphenolic compounds was performed using HPLC method. The antioxidant activity was examined by assessing the various free radical scavenging assays. Five human cancerous cell lines (HeLa, MCF-7, HCT-116, PC-3, and HEK293), one rat colon cancer cell line (RCC 45) and two normal cell lines (NKE and WI-38) were used for evaluating the anticancer activity through methylene blue assay.

Results: The results indicated that ethyl acetate fraction (EAF) and aqueous fraction (AQF) exhibited the remarkable content of flavonoids, phenolics, triterpenoids, and tannins. Both $\mathrm{EAF}$ and $\mathrm{AQF}$ have cytotoxic activity with significant $\mathrm{IC}_{50}$ values but not showed significant antioxidant activity. However, the most powerful anticancer activity was recorded by EAF followed by AQF in a dose-dependent manner. It was also revealed that EAF and AQF were biocompatible with the normal cell lines.

Conclusion: Our principal finding exhibited a potent anticancer activity. Furthermore, it was also indicated that samples contain secondary metabolites like flavonoids, phenolics, triterpenoids, and tannins. We suggest that the further investigation on this herb is effective against various types of ailments including cancer.

Keywords: Diospyros melanoxylon Roxb., Scanning Electron Microscopy (SEM), High-Pressure Liquid Chromatography (HPLC), Polyphenols, Antioxidant, Anticancer

(C) 2018 The Authors. Published by Innovare Academic Sciences Pvt Ltd. This is an open-access article under the CC BY license (http://creativecommons.org/licenses/by/4.0/) DOI: http://dx.doi.org/10.22159/ijpps.2018v10i11.21111

\section{INTRODUCTION}

Cancer is one of the most stressful and life aggressive diseases which implements cruel deaths globally. It is also leading subsequent reason of death in urbanized countries after cardiovascular diseases [1]. Although, chemotherapy is the widespread choice used for the treatment of cancer, but it is frequently connected with a number of negative aspects, viz., nonselective delivery of drugs, multidrug resistance, enhanced drug toxicity, adverse side effects to healthy tissue. The limited success of clinical therapies including radiation, chemotherapy, immunomodulation and surgery in the treatment of cancer, strongly points out that there is an imperative need of alternative strategies in cancer management [2,3].

Oxidative stress or oxidative imbalance is the root cause for many life-threatening diseases. The imbalance between reactive oxygen species (ROS) and reactive nitrogen species (RNS) primarily causes oxidative damage of DNA, RNA, proteins, sugars, and lipids which induce cell damage through endogenous mechanisms. The overproduction of ROS and RNS plays a perfect foundation for the onset of several life-threatening ailments including cancer [4-6].

Recently, medicinal herbs have been widely accepted with escalating awareness all over the World. Now a days, about $65 \%$ of plantbased medicine is used for cancer therapy $[7,8]$. In this regard, identification and characterization of the biocompatibility and efficacy of traditional herbs with antioxidative and anticancer action has been of utmost research interest and have open up a novel alternative to replace harsh and stressful chemotherapies for cancer treatment [9]. Herbs act as a prosperous resource of antioxidant compounds viz., minerals, carotenoids, thiols, vitamins such as ascorbic acid, tocopherols, phenolics, anthocyanin's, stilbenes, flavonoids, lupeols [10-12] and also provides ample resource of anticancer compounds viz., podophyllotoxin, paclitaxel or vincristine, which are capable to dynamically reduce the growth of cancerous cells [12]. It is believed that eating of plant-based antioxidants could be linked with lesser occurrence of numerous human diseases associated to oxidative stress, including cancer [13]. In the future, research on dietary antioxidants from plant sources can play a pivotal role in combating cancer and bringing in innovation in the treatment of cancer through a holistic approach.

D. melanoxylon also known as "kendu" belonging to the family 'Ebenaceae' contains a number of photo elements such as saponins, alkaloids, glycosides, flavonoids, terpenoids, carbohydrates and tannins which are renowned in displaying diverse biological activities together with anti-inflammatory, anti-atherosclerotic, antitumor, antimutagenic, anticarcinogenic, antibacterial, and antiviral activities [14].

The dried flowers of D. melanoxylon are evidenced in Unani medicine for urinary discharges, inflammation of the spleen and enhancement of the blood. The bark extract is used in Ayurveda as an astringent lotion for the eyes. Traditionally D. melanoxylon is also used as diuretic, carminative and antidiabetic. This plant contains an array of bioactive constituents namely, aurone, lupeol, betulin, betulinic acid, ursolic acid, $\alpha$ and $\beta$-amyrin, uvavol, bauerenol, oleanolic acid, hentri-acotanol, $\beta$-sitosterol, 7-mthyljuglone, dimelquinone, dihydroxytriterpenic acid, methoxyderivative of-1, 4naphthquinone, disinidigo $\mathrm{A}$ and $\mathrm{B}$, pentacylic-quinone 
biramentaceone, dimethoxy derivative of 1-naphthol hentriancontane, 8-hydroxy-octadec-10(Z)-enoic acid malvalic acid, bicyclic sesquiterpene, sterculic acid etc. [15]. The leaves are highly esteemed for wrapping "bidis" which is a cheaper rural version of "cigarettes". Their flavor, flexibility, and resistance to decay are the key factors in making their use valuable in the "bidi" industry. $D$. melanoxylon leaf trade is one of the important tribal activities of India and is a good revenue earner for Government, besides providing gainful employment to several tribal peoples [16, 17]. In this context, the broad objective of this study was to present this plant as a future drug candidate for the treatment of cancer through a programmed scientific exploration in terms of it's in vitro antioxidant and anticancer assays.

\section{MATERIALS AND METHODS}

\section{Plant collection}

The leaves of D. melanoxylon known as "kendu" was collected from Dhenkanal District, Bhubaneswar, Odisha. The leaves of $D$. melanoxylon are wildly growing and abundantly available. The plant was authenticated from Botanical survey of India, Central National Herbarium, PO-Botanic Garden, and Howrah-711103. The specimen voucher No. CNH/28/2014/Tech. II was deposited in Department of Pharmaceutical Technology, Jadavpur University, Kolkata, India. The leaves were washed properly, shade dried for $20 \mathrm{~d}$, then cut into small pieces and powdered by a mechanical grinder. The powdered material was stored in an airtight container for experimental use.

\section{Preparation of extract and fractions}

The powdered plant material $1.5 \mathrm{~kg}$ (300 gm $\times 5$ assembly) was extracted with 5 liters ( 1 litre $\times 5$ assembly) of n-hexane using Soxhlet apparatus for $28 \mathrm{~h}$ by hot percolation method for removing fatty and waxy substances. The residue was dried at room temperature and again extracted in the same assembly using ethyl acetate for $36 \mathrm{~h}$ using Soxhlet apparatus. Traditionally, Soxhlet and heat reflux extraction methods have been the first line choice of extraction when it comes to preparation of crude extracts for ethnopharmacological studies [18]. Subsequently, with the ethyl acetate fraction (EAF), two more fractions such as chloroform fraction (CF) and aqueous fraction (AQF) was prepared using liquidliquid partitioning system. Mixing was completed by inverting the funnel 6 times (pressure in the separating funnel was discharged after each invert), whereafter the mixture was allowed to form two layers, and the lower, polar, and the upper, less polar, layers collected separately. The process was repeated six times. The different solvent fractions and n-hexane extract (NHE) were concentrated under vacuum using rotary vacuum evaporator at 40 ${ }^{\circ} \mathrm{C}$ and the dried fractions stored in a refrigerator $\left(4^{\circ} \mathrm{C}\right)$ for further use. The entire fractions and NHE were made solvent free by vacuum evaporation.

\section{Chemicals and reagents}

2,2 diphenyl 1 picrylhydrazide (DPPH) was obtained from SigmaAldrich (St. Louis, MO). Naphthylethylenediamine dihydrochloride (NADPH), hydrogen peroxide $\left(\mathrm{H}_{2} \mathrm{O}_{2}\right), 2$-deoxyribose, EDTA, $\mathrm{Fecl}_{3}$, and ascorbic acid were obtained from LOBA Chemicals, Mumbai, India. Dulbecco's modified Eagle's medium (DMEM), and Fetal bovine serum (FBS) were obtained from Gibco, Grand Island, NY 14072, USA1-716-774-6700. Roswell Park Media Institute (RPMI) 1640, non-essential amino acids, penicillin-streptomycin (PS), Lglutamine, and Gentamicin were obtained from Hi-Media Laboratories Pvt. Ltd., Mumbai, India. Aluminum chloride $\left(\mathrm{AlCl}_{3}\right)$, Potassium acetate, Folin-Ciocalteau reagent, $\mathrm{Na}_{2} \mathrm{CO}_{3}$, trichloroacetic acid, perchloric acid, and glacial acetic acid were obtained from Merck specialties private limited, Mumbai, India. Quercetin and Gallic acid are obtained from Sisco Research Laboratories Pvt. Ltd, Maharashtra, India and SD fine-chem limited, Mumbai, India respectively. All the chemicals and reagents were of analytical grade obtained commercially.

\section{Scanning electron micrographs}

In order to elucidate extraction procedure and to understand the extraction mechanism, scanning electron micrographs (SEM) of the marc obtained from Soxhlet extraction method was taken. After removing the solvent, the remaining $D$. melanoxylon leaf sample was plunged in liquid nitrogen and then cut with a cold knife. The sectioned particles were fixed on a specimen holder with aluminum tape and then sputtered with palladium. The specimen was examined with a QUENTA FEG 250 (Netherland) scanning electron microscope under high vacuum condition and at an accelerating voltage of $20 \mathrm{kV}$ (3500× and 30000× magnification).

\section{Qualitative phytochemicals analysis}

The previously described method by Asaduzzaman et al. was used with slight modification. The tests were performed to find out the presence of active chemical constituents such as carbohydrates, alkaloids, steroids, flavonoids, saponins, glycosides, terpenoids, and tannins [19].

\section{High-performance liquid chromatography (HPLC) analysis}

The various test samples (1 mg) of each fraction (ethyl acetate, aqueous and chloroform) and n-hexane extract were dissolved in 2 $\mathrm{ml}$ methanol and were vortexed for $3 \mathrm{~h}$ to enable proper mixing. The final solution was filtered using $0.22 \mu \mathrm{m}$ membrane filter (Biotech, Germany) prior to high-performance liquid chromatography (HPLC) analysis. The identification of possible bioactive compounds (phenolics and flavonoids) was performed on HPLC (FRC-10A, UFLC, SHIMADZU, JAPAN) with PDA detector using C18, $4.2 \mathrm{~mm} \times 250 \mathrm{~mm}$, $5 \mu \mathrm{m}$ column. The chromatographic separation was carried out using solvent HPLC grade methanol (100\%) and TFA $0.1 \%$ with 1 $\mathrm{ml} / \mathrm{min}$ flow rate using UV-Vis detector at $280 \mathrm{~nm}$ wavelengths at a cool temperature at an injection rate of $10 \mu \mathrm{l}$.

The identification of each compound was established by comparing the retention time of the peaks with those previously obtained by injection of pure standard compounds (gallic acid, ellagic acid, ferulic acid, rutin, and quercetin).

\section{Antioxidant assay \\ Determination of total flavonoid content}

Previously described the method by Ordonez et al. (2006) was used with slight modification $[20,21]$. Total flavonoid was determined based on the formation of a complex flavonoid-aluminum in different samples of D. melanoxylon in triplicate assay. Total flavonoid content was expressed in milligrams of quercetin equivalent per gram of dried sample (mg QE/g sample) using the equation obtained from the calibration curve $Y=0.0006 x+0.001, R^{2}=$ 0.9953 , where $\mathrm{Y}$ is the absorbance and $\mathrm{X}$ is the concentration of quercetin equivalent.

\section{Determination of total phenolic content}

Previously described the method by Koncić et al. (2010) was used with slight modification [22]. The method was performed in triplicate using Folin-Ciocalteu reagent to determine total phenolic content in different samples of $D$. melanoxylon. The Folin-Ciocalteau assess depends on the basis of transmission of electrons in alkaline medium from phenolic compounds to phosphomolybdic/phosphotungstic acid complexes, which are determined spectroscopically at $765 \mathrm{~nm}$. Total phenol content was expressed in milligrams of gallic acid equivalents per gram of dried sample (mg GAE/g sample) using the expression from the calibration $\operatorname{curve}(Y=0.055 x-0.1909), \mathrm{R}^{2}=0.9929$, Where $\mathrm{Y}$ is the absorbance and $\mathrm{x}$ is the concentration of gallic acid equivalent in $\mathrm{mg} / \mathrm{g}$.

\section{Determination of total triterpenoid content}

Previously described the method by Fan and He (2006) was used with slight modification [23]. $100 \mu \mathrm{l}$ of different fractions and NHE $(0.25-1.25 \mathrm{mg} / \mathrm{ml})$ were mixed individually with $150 \mu \mathrm{l}(7.5 \% \mathrm{w} / \mathrm{v})$ vanillin-glacial acetic acid solutions and $500 \mu \mathrm{l}$ of the perchloric acid solution. The sample solutions were heated for $30 \mathrm{~min}$ at $60^{\circ} \mathrm{C}$ and then cooled in an ice-water bath to ambient temperature. After the addition of $2.25 \mathrm{ml}$ glacial acetic acid, each sample solution's absorbance was measured at $548 \mathrm{~nm}$ using a UV-visible spectrophotometer. Total triterpenoid content was expressed in milligrams of lupeol (LPE) equivalents per gram of dried samples 
(mg LPE/g dry sample) using the equation obtained from the calibration curve, $\mathrm{Y}=0.0143 \mathrm{X}+0.1546, \mathrm{R}^{2}=0.9947$.

\section{Determination of total tannin content}

Total tannin content of various samples was evaluated according to Russo et al. (2015) with slight modifications [24]. $500 \mu \mathrm{l}$ of bovine serum albumin (BSA) solution in $0.2 \mathrm{~mol} / \mathrm{l}$ acetic buffer, pH 5.7 with $0.17 \mathrm{~mol} / \mathrm{l} \mathrm{NaCl}(1.5 \mathrm{mg} / \mathrm{ml})$ was added to various concentrations of samples $(0.25-1.25 \mathrm{mg} / \mathrm{ml}$ )and mixed carefully. After $20 \mathrm{~min}$, the samples were centrifuged at $5000 \mathrm{~g}$ for $20 \mathrm{~min}$. The supernatant was removed, and the pellet dissolved in $1 \mathrm{ml}$ of $1 \%$ aqueous solution of sodium dodecyl sulphate (SDS) and $4 \%$ triethanolamine followed by addition of $250 \mu \mathrm{l}$ of $0.01 \mathrm{~mol}^{-1} \mathrm{Fecl}_{3}$ in $0.01 \mathrm{~mol} / \mathrm{l} \mathrm{HCl}$. After $45 \mathrm{~min}$ the absorbance was recorded at $510 \mathrm{~nm}$. Total tannin content was expressed as mg of tannic acid equivalent/g of sample (mg TAE/g of sample) using the equation obtained from the calibration curve $\mathrm{Y}=$ $0.046 \mathrm{x}+0.0796, \mathrm{R}^{2}=0.9974$.

\section{DPPH scavenging assay through thin layer chromatography (TLC)}

The antioxidant activity of different samples obtained from $D$. melanoxylon was evaluated by a previously reported method of Singh and Kumari (2015) with slight modification [25]. Various samples (3 mg, diluted in methanol, 1:10) were spotted on a TLC plate. The TLC plate was then developed in methanol and ethyl acetate in the ratio of $60: 40$. The prepared DPPH solution $(0.2 \%$ in methanol) was sprayed on the developed plate and allowed to stand for $45 \mathrm{~min}$ at room temperature. The purple color of DPPH was lightened, and the formation of yellow spot showed the presence of antioxidant activity.

\section{Antioxidant assay through DPPH}

Previously described the method by Sharma and Bhat (2009) was used with slight modification [26, 27]. Total antioxidant activities of different fractions and NHE were measured on the basis of electron donating ability by bleaching a purple solution of 2, 2-diphenyl 1 picrylhydrazyl (DPPH) at different concentrations $(100-500 \mu \mathrm{g} / \mathrm{ml})$. Samples were added to $0.5 \mathrm{ml}$ of $0.2 \mathrm{mmol} / \mathrm{l} \mathrm{DPPH}$ solution. The samples were kept at dark for $45 \mathrm{~min}$, and absorbance was taken against a blank at $517 \mathrm{~nm}$. Ascorbic acid (AA) was used as a positive control and results were expressed as half maximum inhibitory concentration $(\mu \mathrm{g} / \mathrm{ml})$ in the triplicate assay. The percentage of scavenging ability of different fractions and NHE were calculated using the following equation.

$$
\begin{aligned}
& \text { DPPH Scavenging activity (\%) } \\
& \text { Absorbance of Control }- \text { Absorbance of sample } \\
& \text { Absorbance of Control }
\end{aligned} 100
$$

Where Absorbance of control is the Absorbance of (DPPH+ Methanol) and Absorbance of sample is the Abs of (DPPH+samples or standard).

\section{Nitric oxide scavenging assay}

Nitric oxide scavenging activity of entire fractions and NHE were performed by the method previously described by Sreejayan and Rao(1997) with slight modification [28]. Sodium nitroprusside (10 mmol), in phosphate-buffered saline, was mixed with samples of $D$. melanoxylon at different concentrations $(100-500 \mu \mathrm{g} / \mathrm{ml})$. The mixture was dissolved in water and incubated at room temperature for $150 \mathrm{~min}$. Griess reagent $(0.5 \mathrm{ml})$, which contain $1 \%$ sulfanilamide, $2 \% \mathrm{H}_{3} \mathrm{PO}_{4}$ and $0.1 \% \mathrm{~N}$-(1-naphthyl) ethylenediamine dihydrochloride, was added to the mixture after the incubation period. The absorbance of the chromophore formed was read at 546 $\mathrm{nm}$. Ascorbic acid and the same reaction mixture without samples were employed as positive and negative control, respectively.

\section{Reducing power assay}

The reducing power of different samples of D. melanoxylon was estimated by the technique of Luqman et al. (2009) with little modification [29]. The different concentrations of samples (100-500 $\mu \mathrm{g} / \mathrm{ml})$ were mixed with $0.75 \mathrm{ml}(0.2 \mathrm{M})$ phosphate buffer $(\mathrm{pH} \mathrm{6.6})$ and $0.75 \mathrm{ml} \mathrm{(1 \% )} \mathrm{K}_{4} \mathrm{FeCN}_{6}$ and incubated for $30 \mathrm{~min}$ at $45{ }^{\circ} \mathrm{C}$ in a water bath followed by precipitation with $0.75 \mathrm{ml}(10 \%)$ trichloroacetic acid. The supernatant $(1.5 \mathrm{ml})$ was diluted with the same volume of double distilled water and ferric reducing abilities of the samples were confirmed by addition of $0.1 \mathrm{ml}(0.10 \%) \mathrm{FeCl}_{3}$. The absorbance of reaction mixture was noted at $700 \mathrm{~nm}$ against control. More absorbance of the reaction mixture pointed to better reducing power.

\section{Hydroxyl radical scavenging assay}

The hydroxyl radical scavenging activity was measured through a previously reported method by Irshad et al. (2012) by means of Fenton reaction [30]. $1.5 \mathrm{ml}$ of various concentration of samples (100-500 $\mu \mathrm{g} / \mathrm{ml})$ were mixed with $60 \mu \mathrm{l}$ (1.0 mmol) Fecl $_{3}, 90 \mu \mathrm{l}(1$ mmol) 1, 10-phenanthroline, $2.4 \mathrm{ml}(0.2 \mathrm{M})$ phosphate buffer ( $\mathrm{pH}$ $7.8)$, and $150 \mu \mathrm{l}(0.17 \mathrm{M}) \mathrm{H}_{2} \mathrm{O}_{2}$. The absorbance of reaction mixture was recorded at $560 \mathrm{~nm}$ after incubation period of $10 \mathrm{~min}$ at $40{ }^{\circ} \mathrm{C}$ temperature in triplicate method. Ascorbic acid was used as standard sample. The hydroxyl radicals scavenging activity was calculated according to the following equation.

$$
(\%) \text { Inhibition }=\frac{\text { Absorbance of Control }- \text { Absorbance of sample }}{* 100 \quad \text { Absorbance of Control }}
$$

Where, Ae is the absorbance of control and Ao is the absorbance of tested samples.

\section{Hydrogen peroxide scavenging assay}

Previously described method by Rahmat et al. (2012) was used with slight modification [31]. $2 \mathrm{mmol}$ solution of hydrogen peroxide was prepared in $50 \mathrm{mmol}$ phosphate buffer $(\mathrm{pH} 7.4)$. The reading of hydrogen peroxide concentration was noted calorimetrically at 230 nm by means of the molar extinction coefficient for $\mathrm{H}_{2} \mathrm{O}_{2}$ of $0.1 \mathrm{ml}$ (81 mol-1 cm-1). Samples in different concentration (100$500 \mu \mathrm{g} / \mathrm{ml}$ ) and standard ascorbic acid were transferred into the Eppendorf with the help of micropipette and their volumes were made up to $0.4 \mathrm{ml}$ with $50 \mathrm{mmol}$ phosphate buffer ( $\mathrm{pH} \mathrm{7.4)}$ ). Then transfer the solution in tubes and vortexed after adding $0.6 \mathrm{ml}$ hydrogen peroxide solution. Absorbance of hydrogen peroxide was recorded at $230 \mathrm{~nm}$ after $15 \mathrm{~min}$, against negative control. $50 \mathrm{mmol}$ phosphate buffer without hydrogen peroxide was used as negative control. Experiments were performed in triplicates. Hydrogen peroxide scavenging capacity was intended by the formula:

$$
\% \text { Inhibition }=(1-\mathrm{Ae} / \mathrm{Ao}) * 100
$$

Where, Ao is the absorbance without sample, and Ae is absorbance with sample.

\section{Cell lines and culture conditions}

All the cell lines were ordered from the American Type Culture Collection (ATCC) and those used in this study were breast cancer cell (MCF-7), human colon carcinoma cell (HCT 116), cervical cancer cells (HeLa), prostate cancer cells (PC-3), Human epithelial kidney (HEK293), and rat colon cancer cells (RCC 45); normal human kidney epithelium cells (NKE) and normal lung tissue cells (WI-38). MCF-7, HCT-116, HEK293, and WI-38 cells were grown in DMEM medium with $10 \%$ FBS and 1\% penicillin-streptomycin. HeLa, PC-3, NKE, and RCC45 cells were grown in RPMI 1640 medium with $10 \%$ FBS and 1\% penicillin-streptomycin. All cells were supplemented in a humidified atmosphere at $37^{\circ} \mathrm{C}$ in $5 \% \quad \mathrm{CO}_{2}$. Afterward, the exhausted medium was removed, replaced with fresh medium, and incubated again for $24 \mathrm{~h}$. The cell cultures were then washed with PBS and were suspended using trypsin. Fresh medium was added to the cells.

\section{Cytotoxicity assay}

The methylene blue cytotoxicity assay was carried out according to the method previously described by Rathore et al. (2014) with slight modification [32]. Cells were seeded at $1.5 \times 10^{4}$ cells in each well of 96-well plate using $100 \mu \mathrm{l}$ of fresh culture medium and were allowed to attach for overnight. Cell counts were made to determine cell viability by using the Tryptan Blue exclusion method [33]. For screening, the cells (60-70\% confluence) were 
treated with the fractions at different concentrations. Afterward, in order to obtain a curve, the most active fractions were tested for cytotoxicity at $20,40,60,80,100 \mu \mathrm{g} / \mathrm{ml}$ concentrations. After $48 \mathrm{~h}$ of treatment, the medium was removed from each well; methylene blue was added and incubated for 90 min on a shaker followed by decanting and washing with water to remove the extracellular dye. A solution $(0.1 \mathrm{~N} \mathrm{HCl})$ was then added for detaching the dyed cells. The colorimetric assay at $580 \mathrm{~nm}$ was performed on 96 wells microplate. The cytotoxicity effects of different samples were calculated as a percentage of cell growth inhibition with respect to control and IC $\mathrm{C}_{50}$ value calculated. The assay was performed in triplicates.

\section{Statistical analysis}

All tests were performed as three independent experiments; each carried out in triplicate. Results were expressed as mean values with standard deviations (mean $\pm \mathrm{SD}$ ) and were subjected to two-way analysis of variance (ANOVA). All the data were calculated using graph-Pad Prism version 5.01-2011 software (Graph Pad Software, Inc., La Jolla, CA, USA).

\section{RESULTS}

In this study, we had prepared four samples from a traditionally used medicinal plant D. melanoxylon for the management of oxidative stress-related ailments and were examined for in vitro antioxidant and anticancer activity. Two out of these exhibited momentous anticancer potential against various cancerous cell lines.

\section{Extraction mechanism}

In order to study cell damage during extraction, the D. melanoxylon leaf samples were examined by scanning electron microscopy. Fig. 1A and B represent the micrographs of the Soxhlet extraction sample at different magnification, both at the surface and cellular levels. The changes observed for Soxhlet extraction showed ruptures took place at the surface of leaf samples accompanied by a widening of the cellular channels. However, the surface of the sample was destroyed after extraction followed by massive widening or opening up of the cellular pores [34].
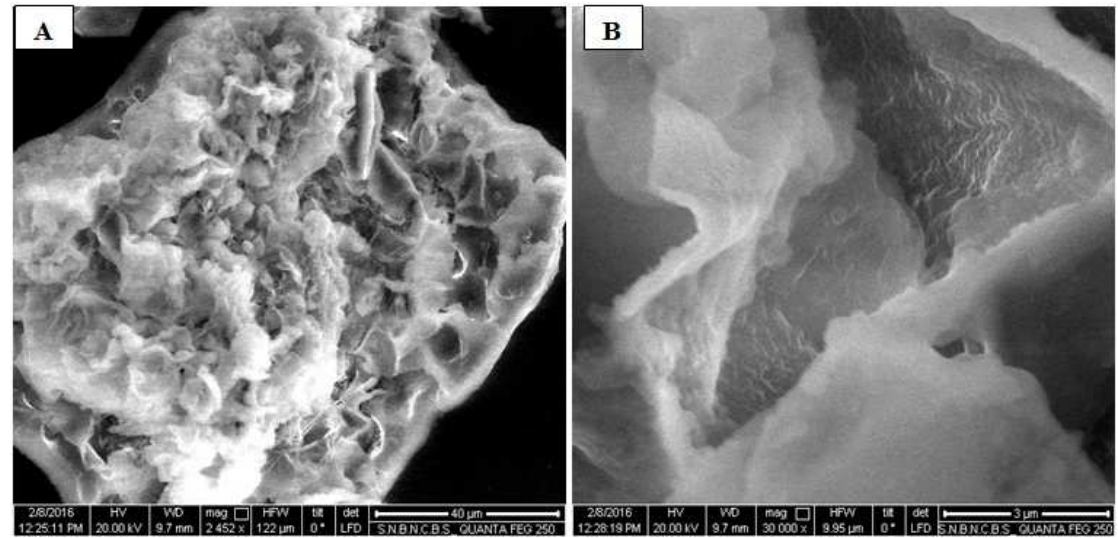

Fig. 1: Scanning electron micrographs of D. melanoxylon leaf sample after soxhlet extraction. (A) Disruption of surface morphology and (B) Widening of cellular channels and internal pores to facilitate leaching of the phytoconstituents

\section{Qualitative phytochemicals analysis}

The different samples of D. melanoxylon viz., EAF, AQF, CF, and NHE were scrutinized qualitatively for the presence of various phytochemicals. The various samples confirmed the presence of carbohydrates, flavonoids, saponins, glycosides, tannins, and terpenoids. Alkaloids and steroid were found to be absent in the various samples. Quantitative analysis revealed that the EAF contained the highest amount of phenolics, flavonoids, and triterpenoids followed by AQF, CF and NHE.

\section{High-performance liquid chromatography (HPLC) analysis}

Various samples (EAF, AQF, CF and NHE) obtained from $D$. melanoxylon leaves were analyzed for identification of polyphenolic (phenolic acids and flavonoids) compounds by HPLC-DAD analysis. Typical chromatograms of different samples and standards are presented in fig. 2. Compounds were identified by comparison of retention times with standard reference compounds viz., four phenolic compounds (gallic acid, ellagic acid, ferulic acid, and rutin) and one flavonoid (quercetin).

Phenolic and flavonoid derivatives were detected in the HPLC-DAD profiles of the four samples. In the group of phenolic acids, gallic acid was the major compound detected in all the samples with retention time 12.277 min. Ferulic acid was the minor compound detected in all the samples with retention time 23.017 min. Subsequent to this, rutin was the second major compound in all the samples with retention time $24.708 \mathrm{~min}$. Ellagic acid was present in the entire sample with retention time 25.454. As revealed from the area under the curve ellagic acid content was found to be more in EAF comparatively when compared to quercetin whose retention time was $28.08 \mathrm{~min}$. Among the different fractions of $D$. melanoxylon leaf, EAF was exposed as an effective solvent for extraction of most of phenolic acids and flavonoid.

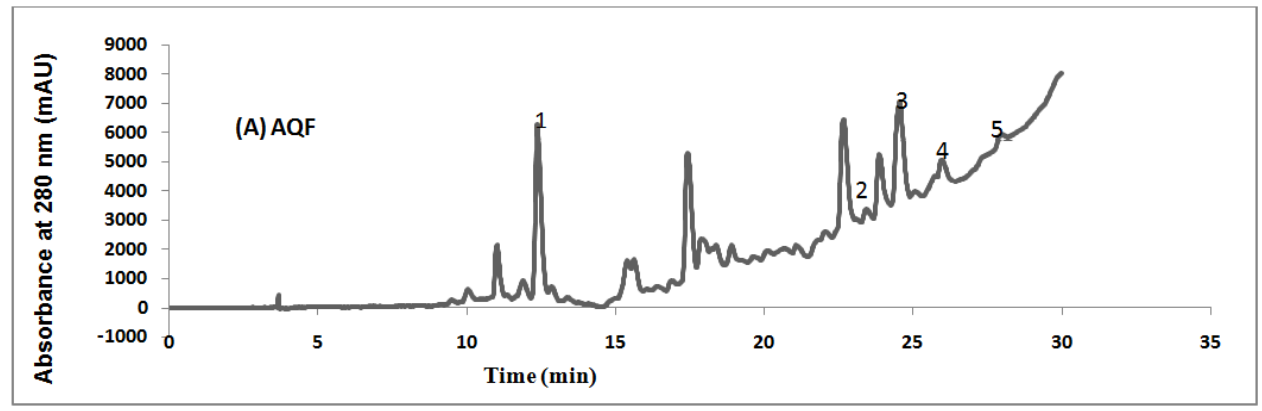



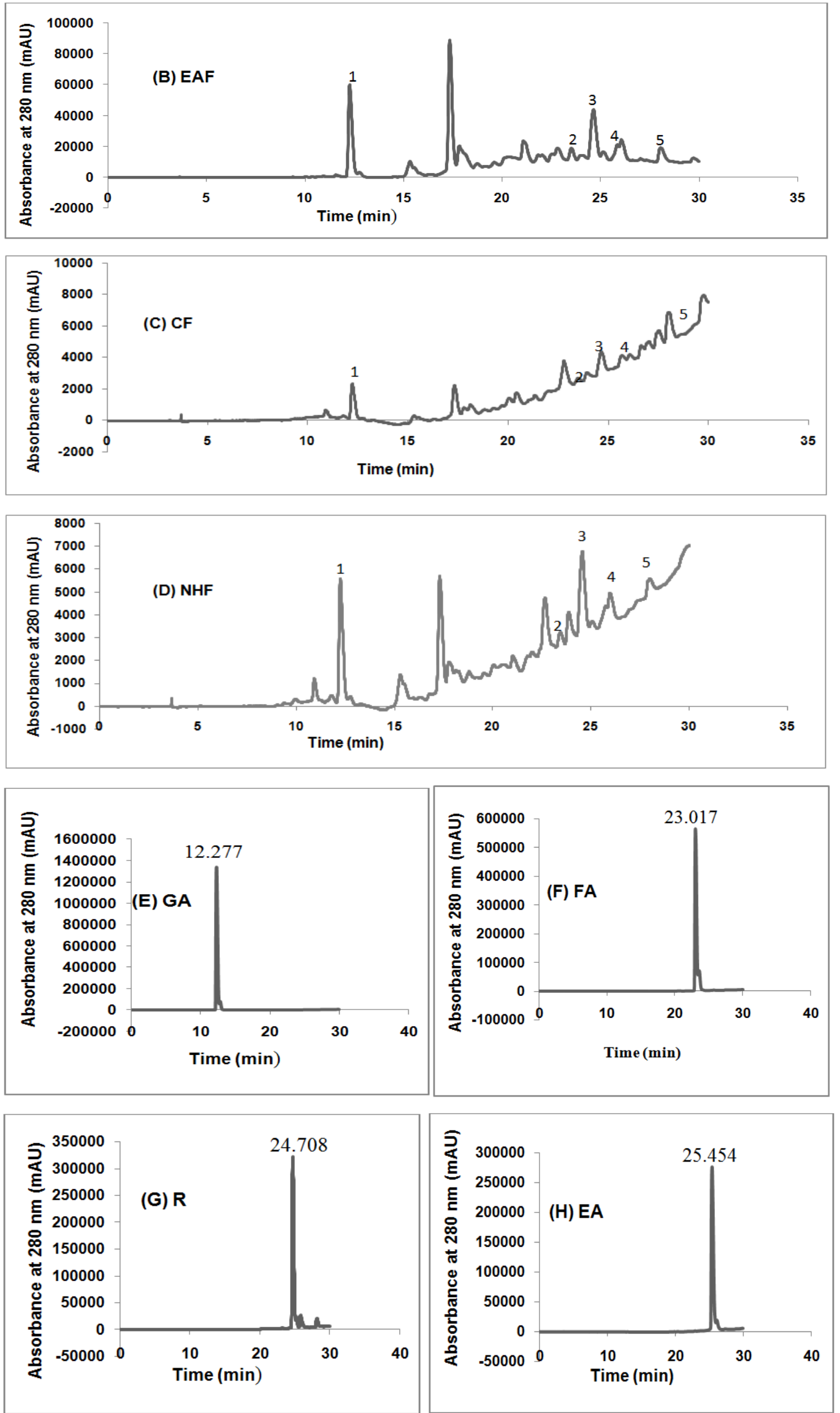


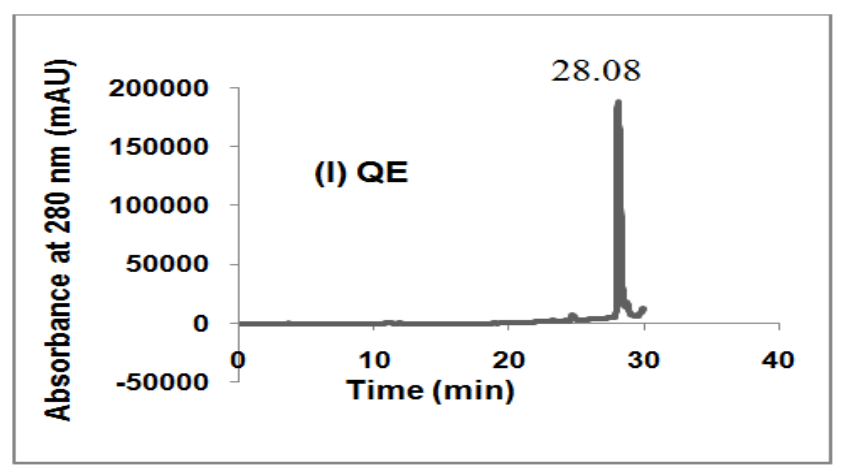

Fig. 2: Identification of the major polyphenolic compounds in chromatograms of (A) AQF=aqueous fraction (B) EAF=ethyl acetate fraction, (C) CF=chloroform fraction, (D) NHE=n-hexane extract, (E) GA=gallic acid, (F) FA=ferulic acid, (G) R=Rutin, (H) EA=ellagic acid, and (I) $\mathrm{QE}=$ quercetin. Peak 1=Gallic acid; 2 =Ferulic acid; 3 =Rutin; 4 =Ellagic acid; 5 =Quercetin

\section{Total flavonoid and phenolic content}

Total flavonoid and phenolic content were analyzed systematically, and results are shown in table 1 . The contents of flavonoid compounds in different fractions varied as such $\mathrm{EAF}>\mathrm{AQF}>\mathrm{NHE}>\mathrm{CF}$ with values $53.04 \pm 1.93 ; 48.96 \pm 0.285 ; 13.75 \pm 0.54$ and $11.97 \pm 0.31 \mathrm{mg} \mathrm{QE} / \mathrm{g}$ dry sample, respectively. The contents of phenolic compounds so determined for different plant fractions varied in the following sequence $\mathrm{EAF}>\mathrm{AQF}>\mathrm{NHE}>\mathrm{CF}$, with values $131.4 \pm 0.44 ; 124.8 \pm 0.24$; $15.87 \pm 0.04$ and $7.73 \pm 0.18 \mathrm{mg} \mathrm{GAE} / \mathrm{g}$ dry sample, respectively. The results are also in agreement with the findings of HPLC analysis.

\section{Total triterpenoid and tannin content}

Total triterpenoid and tannin content was analyzed systematically, and results are shown in table 1 . The contents of triterpenoid compounds varied in different fractions accordingly, $\mathrm{EAF}>\mathrm{AQF}>\mathrm{CF}>\mathrm{NHE}$ with values $53.98 \pm 1.95$; $33.95 \pm 2.4 ; 20.19 \pm 1.66$ and $10.31 \pm 1.75 \mathrm{mg}$ LPE/g dry sample, respectively. The contents of tannin compounds varied in different fractions accordingly, $\mathrm{EAF}>\mathrm{AQF}>\mathrm{NHE}>\mathrm{CF}$ with values $79.60 \pm 0.60 ; 72.40 \pm 0.18 ; 12.85 \pm 0.10$ and $12.12 \pm 0.11 \mathrm{mg} \mathrm{LPE} / \mathrm{g}$ dry sample, respectively.

Table 1: Total flavonoid, phenolic, triterpenoid, and tannin content in different samples of D. melanoxylon

\begin{tabular}{|c|c|c|c|c|}
\hline Fractions & $\begin{array}{l}\text { Total flavonoids as } \\
\text { quercetin equivalent (mg } \\
\text { QE/g sample) }\end{array}$ & $\begin{array}{l}\text { Total phenolics as gallic acid } \\
\text { equivalent (mg GAE/g } \\
\text { sample) }\end{array}$ & $\begin{array}{l}\text { Total triterpenoids as lupeol } \\
\text { equivalent (mg LPE/g } \\
\text { sample) }\end{array}$ & $\begin{array}{l}\text { Total tannins as tannic acid } \\
\text { equivalent (mg LPE/g } \\
\text { sample) }\end{array}$ \\
\hline EAF & $53.04 \pm 1.93$ & $131.4 \pm 0.44$ & $53.98 \pm 1.95$ & $79.60 \pm 0.60$ \\
\hline $\mathrm{AQF}$ & $48.96 \pm 0.285$ & $124.8 \pm 0.24$ & $33.95 \pm 2.41$ & $72.40 \pm 0.18$ \\
\hline $\mathrm{CF}$ & $11.97 \pm 0.31$ & $7.73 \pm 0.18$ & $20.19 \pm 1.66$ & $12.12 \pm 0.11$ \\
\hline NHE & $13.75 \pm 0.54$ & $15.87 \pm 0.04$ & $10.31 \pm 1.75$ & $12.85 \pm 0.10$ \\
\hline
\end{tabular}

Each value in the table is represented as mean $\pm \mathrm{SD}(\mathrm{n}=3) . \mathrm{QE}=$ quercetin equivalent, GAE= gallic acid equivalent, $\mathrm{LPE}=\mathrm{lupeol}$ equivalent.

\section{DPPH scavenging assay}

The discoloration of the purple color of the DPPH on TLC plates confirmed the positive antioxidant activity of the EAF, AQF, and CF. It was also seen that NHE did not show any color change. Different fractions of D. melanoxylon confirmed significant scavenging activities for DPPH free radicals as shown in fig. 3. EAF showed the highest scavenging activity (lowest $\mathrm{IC}_{50} ; 346.11 \pm 1.33 \mu \mathrm{g} / \mathrm{ml}$ ) followed by AQF $(430.3 \pm 0.87 \mu \mathrm{g} / \mathrm{ml}), \mathrm{CF}(463.27 \pm 0.95 \mu \mathrm{g} / \mathrm{ml})$ and NHE $(672.43 \pm 4.44 \mu \mathrm{g} / \mathrm{ml})$ in table 2 .

\section{Nitric oxide scavenging assay}

This is supported by the principle that sodium nitroprusside in samples at various concentrations which produces nitric oxide and interacts with oxygen to produce nitrite ions that can be calculated using Griess reagent. Samples mainly scavenge the nitric oxide and fight with oxygen which decreased the creation of nitrite ions. Nitric oxide scavenging activity is shown in fig. 3. EAF was found to be more potent $\left(\mathrm{IC}_{50} 349.38 \pm 7.3333 \mu \mathrm{g} / \mathrm{ml}\right.$ ) when compared to other fractions (table 2).

\section{Hydroxyl scavenging assay}

An enormously reactive entity in biological systems is the $\mathrm{OH}$ radical. It is one of the most destructive geniuses in free radical pathology, capable of damaging the bimolecular integrity of the living cells. These radical unites among nucleotides in DNA and cause strand breakage leading to carcinogenesis, mutagenesis, and cytotoxicity. Hydroxyl radical $(\mathrm{OH})$ scavenging aptitude of different samples is openly linked to its antioxidant activity. EAF was mainly efficient (IC $50325.17 \pm 5.76 \mu \mathrm{g} / \mathrm{ml}$ ) followed by AQF (IC ${ }_{50} 358.1 \pm 4.04$ $\mu \mathrm{g} / \mathrm{ml}), \mathrm{CF}\left(\mathrm{IC}_{50} 397.67 \pm 4.66 \mu \mathrm{g} / \mathrm{ml}\right.$ ), and NHE (IC $50476.89 \pm 0.06$ $\mu \mathrm{g} / \mathrm{ml})$, shown in table 2 . The hydroxyl scavenging activity of ascorbic acid was found to be $80.43 \pm 2.23 \mu \mathrm{g} / \mathrm{ml}$, shown in fig. 3 .

\section{Hydrogen peroxide scavenging assays}

Hydrogen peroxide is transformed into free radical termed $\mathrm{OH}$ in living cells and counter with biomolecules subsequently causing tissue injury and cell death. So it is anticipated that these are noxious to living cells sometimes, but it is basically non-reactive. Table 2 shows the $\mathrm{IC}_{50}$ of hydrogen peroxide scavenging effect by various samples along with ascorbic acid and fig. 3 shows the

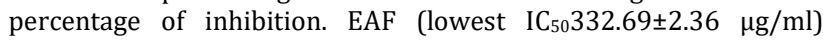
noticeably scavenged the free radicals and was mainly effective than other samples. Inhibitory concentration of standard ascorbic acid was found to be $80.07 \pm 0.83 \mu \mathrm{g} / \mathrm{ml}$.

\section{Reducing power assay}

Reducing power assay is based on the principle of electron-donating activity, which is an important mechanism of phenolic antioxidant action [35]. In this assay, the presence of antioxidants in the samples would result in the reducing of ferric $\left(\mathrm{Fe}^{3+}\right)$ to ferrous form $\left(\mathrm{Fe}^{2+}\right)$ by donating an electron. Amount of ferrous $\left(\mathrm{Fe}^{2+}\right)$ complex can then be monitored by measuring the absorbance of Perl's Prussian blue at $700 \mathrm{~nm}$. Increasing absorbance at $700 \mathrm{~nm}$ indicates an increase in the reductive ability. Fig. 3 shows dose-dependent response for reducing power assay and $\mathrm{IC}_{50}$ values are depicted in table 2 . 

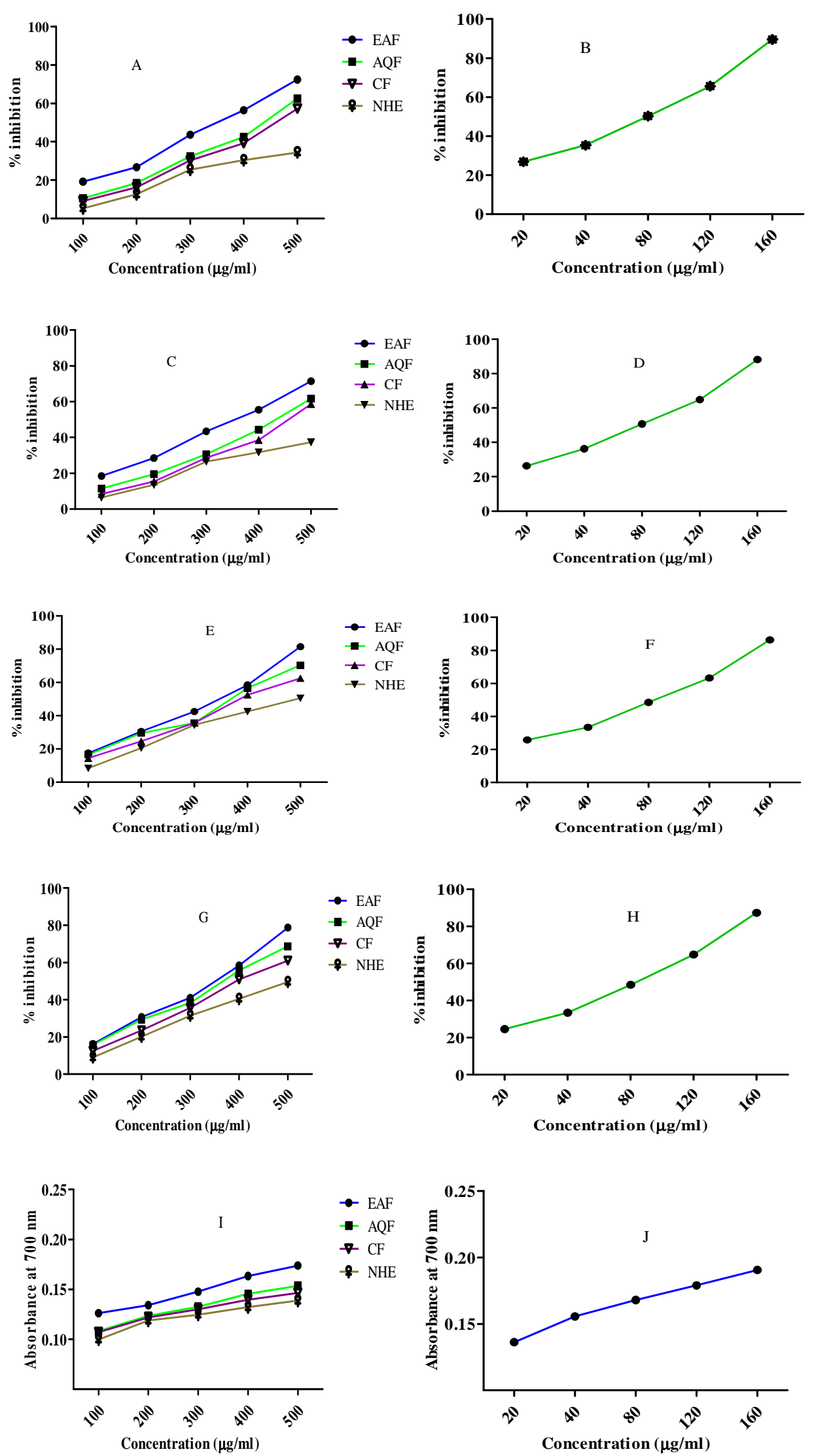

Fig. 3: In-vitro antioxidant screening of (A) fractions on DPPH, (B) ascorbic acid on DPPH, (C) nitric oxide assay of fractions, (D) nitric oxide assay of ascorbic acid, (E) hydroxyl scavenging assay of fractions, (F) hydroxyl scavenging assay of ascorbic acid, (G) hydrogen peroxide assay of fractions, $(\mathrm{H})$ hydrogen peroxide assay of ascorbic acid, (I) reducing power assay of fractions, and $(\mathrm{J})$ reducing power assay of ascorbic acid. Each value in the table is represented as mean $\pm \operatorname{SD}(n=3)$ 
Table 2: IC $\mathrm{I}_{50}(\mu \mathrm{g} / \mathrm{ml})$ of different fractions of $D$. melanoxylon for various antioxidant systems

\begin{tabular}{lllll}
\hline Treatment & $\begin{array}{l}\text { DPPH radical } \\
\text { scavenging assay }\end{array}$ & $\begin{array}{l}\text { Hydroxyl scavenging } \\
\text { assay }\end{array}$ & $\begin{array}{l}\text { Hydrogen peroxide } \\
\text { scavenging assay }\end{array}$ & $\begin{array}{l}\text { Reducing power } \\
\text { assay }\end{array}$ \\
\hline EAF & $346.11 \pm 1.33$ & $325.17 \pm 5.76$ & $332.69 \pm 2.36$ & $237.94 \pm 13.93$ \\
AQF & $430.3 \pm 0.87$ & $358.1 \pm 4.04$ & $361.46 \pm 2.14$ & $375.39 \pm 9.08$ \\
CF & $463.27 \pm 0.95$ & $397.67 \pm 4.66$ & $398.06 \pm 6.35$ & $424.50 \pm 29.07$ \\
NHE & $672.43 \pm 4.44$ & $476.89 \pm 0.06$ & $496.98 \pm 19.38$ & $493.24 \pm 15.22$ \\
AA & $76.02 \pm 0.39$ & $80.43 \pm 2.23$ & $80.07 \pm 0.83$ & $22.33 \pm 1.30$ \\
\hline
\end{tabular}

Each value in the table is represented as mean $\pm \operatorname{SD}(n=3)$.

\section{Anticancer effect}

Methylene blue assay was used to screen the possible cytotoxic activity of different samples against five human cancer cells lines (HeLa, MCF-7, HCT116, PC-3, and HEK-293), one rat colon cancer cell line (RCC 45) and two normal cell lines (NKE and WI-38). Different samples caused loss of cell viability in a dose-dependent manner.

$\mathrm{EAF}$ and $\mathrm{AQF}$ of D. melanoxylon leaves exhibited the highest cytotoxicity on all the tested cell lines as shown in fig. 4. NHE demonstrated moderate anticancer activity against observed cancer cells in our study. To the best of our knowledge, these two fractions had not been investigated for their anticancer activity. Interestingly, all the samples showed good biocompatibility against the normal cell lines as depicted in fig. 4. Further, the most active samples were selected to study the dose-response cytotoxicity effect. The median inhibitory concentration $\left(\mathrm{IC}_{50}\right)$ values for the most active fractions were calculated for all the tested cell lines, and the values are shown in table 3.

Interestingly, all the samples showed either mild or negligible cytotoxicity against both the normal cell lines (NKE and WI-38) which were used as the model normal cell lines. (a)

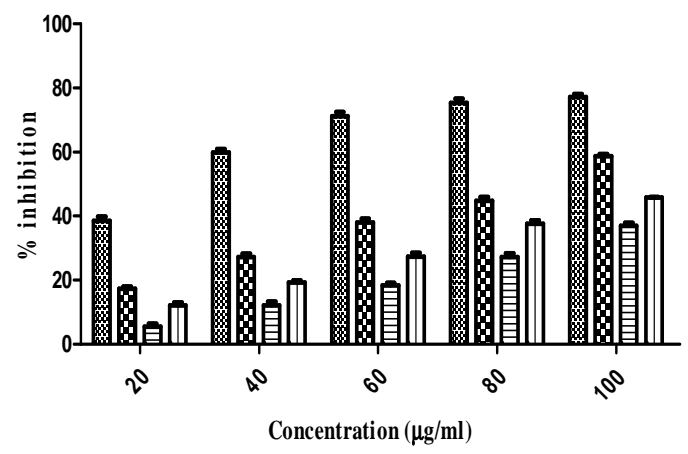

(c)

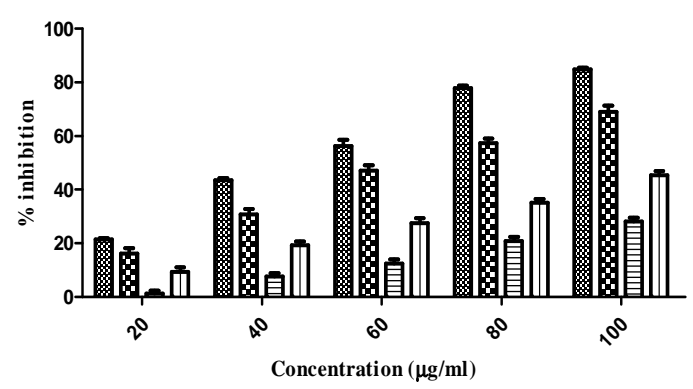

(g)

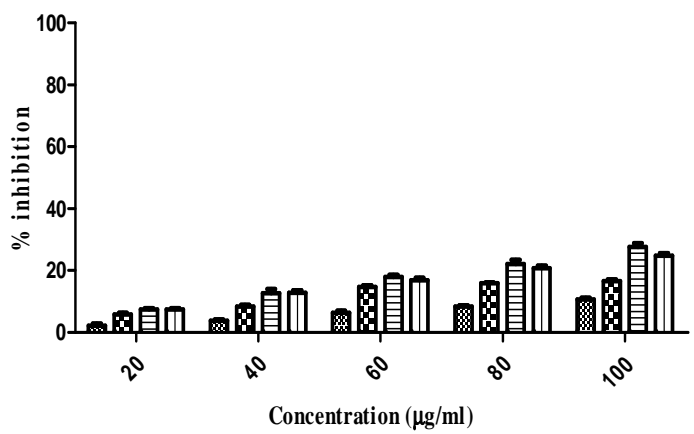

(b)

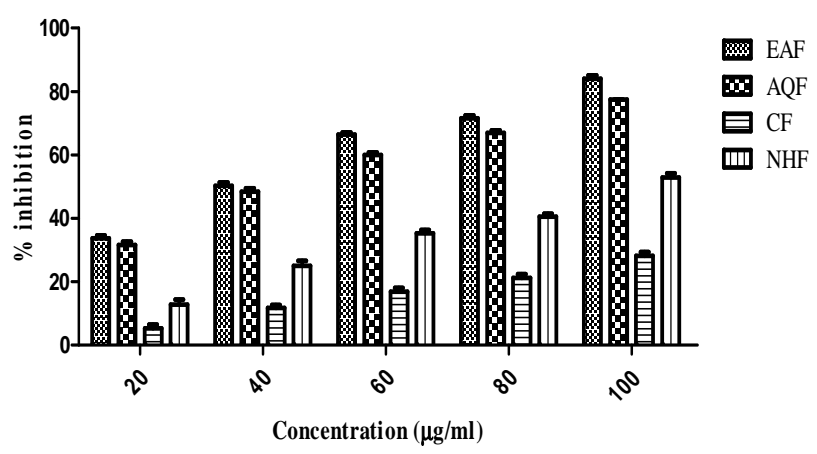

(d)

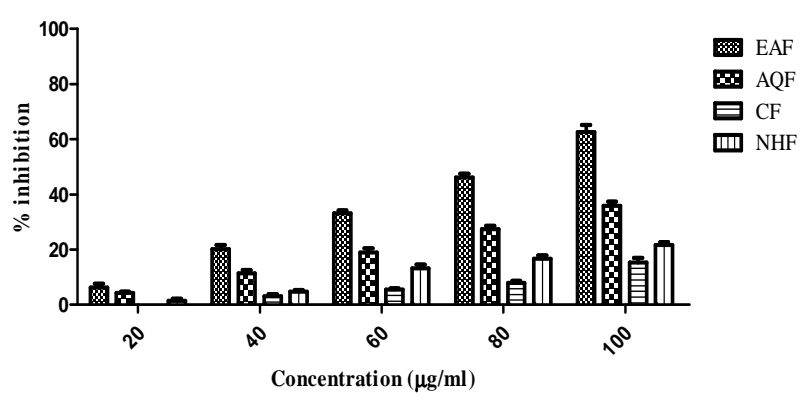

(h)
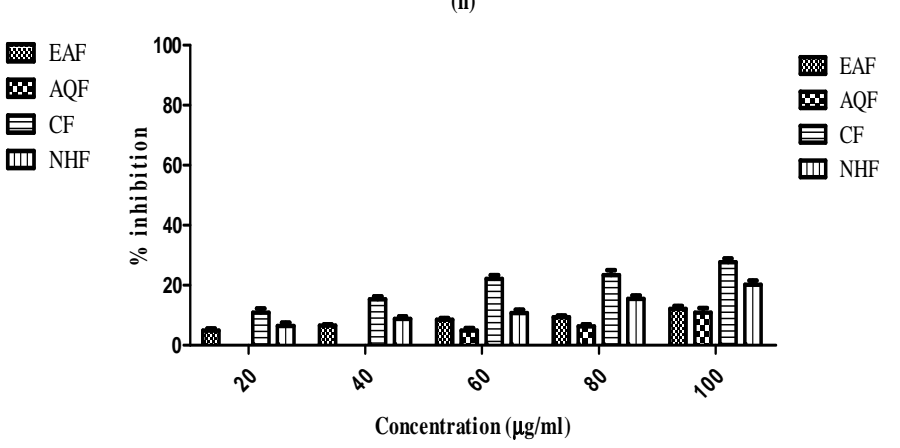
(e)

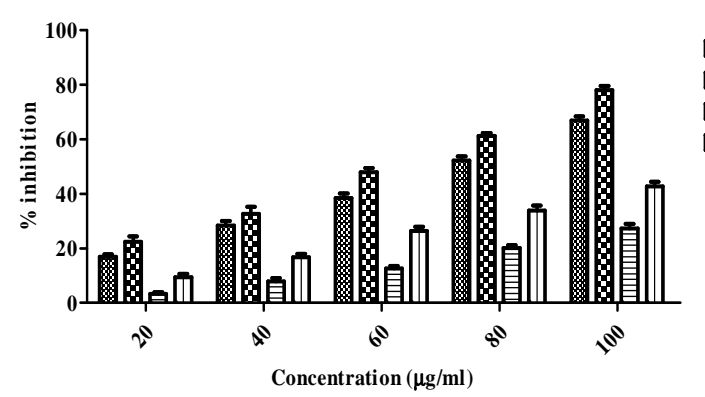

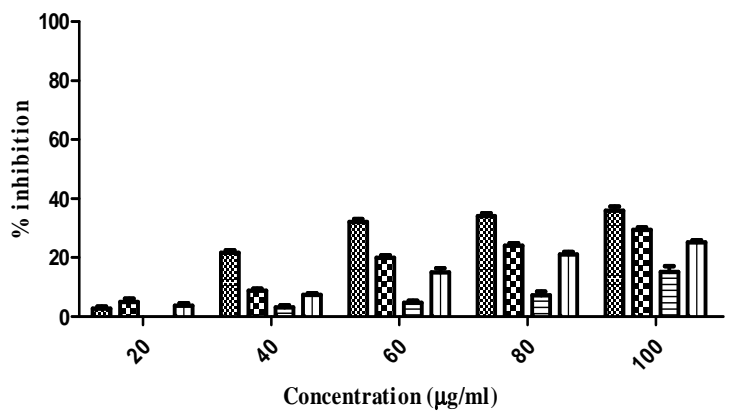

Fig. 4: Cell toxicity studies of different samples on (a) HeLa, (b) MCF-7, (c) HCT116, (d) PC-3, (e) HEK293, (f) RCC45, (g) WI-38, and (h) NKE. Each value in the table is represented as mean $\pm S D(n=3)$

Table 3: $\mathrm{IC}_{50}(\mu \mathrm{g} / \mathrm{ml})$ of different fractions of D. melanoxylon for various anticancer systems

\begin{tabular}{|c|c|c|c|c|c|c|c|c|}
\hline \multirow[t]{2}{*}{ Treatment } & \multicolumn{6}{|c|}{ Carcinoma cell lines } & \multicolumn{2}{|c|}{ Normal cell lines } \\
\hline & HeLa & MCF-7 & HCT116 & PC-3 & HEK293 & RCC45 & NKE & WI-38 \\
\hline$\overline{\mathrm{EAF}}$ & $28.96 \pm 2.17$ & $\begin{array}{l}41.52 \\
\pm 1.4\end{array}$ & $51.59 \pm 0.85$ & $83.68 \pm 4.08$ & $75.18 \pm 1.83$ & $122.77 \pm 3.7$ & $562.00 \pm 114.54$ & $468.44 \pm 15.29$ \\
\hline $\mathrm{AQF}$ & $85.63 \pm 2.69$ & $\begin{array}{l}47.41 \\
\pm 1.10\end{array}$ & $69.2 \pm 2.79$ & $136.86 \pm 6.93$ & $62.04 \pm 2.10$ & $161.59 \pm 2.15$ & $390.97 \pm 48.02$ & $318.42 \pm 5.95$ \\
\hline $\mathrm{CF}$ & $136.86 \pm 5.63$ & $\begin{array}{r}182.72 \\
\pm 19.71\end{array}$ & $168.32 \pm 14.38$ & $207.7 \pm 12.85$ & $180.34 \pm 19.54$ & $329.79 \pm 81.25$ & $207.31 \pm 21.23$ & $190.68 \pm 14.65$ \\
\hline NHF & $110.32 \pm 2.67$ & $\begin{array}{r}95.02 \\
\pm 3.62 \\
\end{array}$ & $111.77 \pm 3.25$ & $311.47 \pm 45.40$ & $116.30 \pm 1.89$ & $186.73 \pm 13.60$ & $282.51 \pm 24.25$ & $216.18 \pm 1.66$ \\
\hline
\end{tabular}

Each value in the table is represented as mean $\pm \operatorname{SD}(n=3)$.

\section{DISCUSSION}

SEM images could give a clear evidence of widening of cellular channels allowing easy entry of the solvent into the plant matrix. Solid-liquid extraction is thus the best method for the transfer of solute from one phase to another. This transfer mechanism is driven by capillary flow and depends upon the viscosity of the solvent. In Soxhlet extraction, mass transfer happens from the inside to the outside while heat transfer happens from the outside to the inside. This observation suggests that Soxhlet treatment affects the structure of the cell due to the sudden temperature rise [36].

The qualitative phytochemical screening for various fractions of $D$. melanoxylon was carried out. The results of phytochemical screening reveals that the leaves used for the extraction procedure were imperative and adequate full-fledged to proliferate and contain metabolites needed to confirm various protective mechanisms. The preliminary phytochemical studies indicated the presence of carbohydrates, alkaloids, flavonoids, saponins, triterpenoids, glycosides, and tannins in the various sample. A number of scientific reports indicate triterpenoids; steroids and phenolic compounds such as tannins, coumarins, and flavonoids have chemopreventive role in cancer through their effects on signal transduction in cell proliferation and angiogenesis [37, 38]. Furthermore, flavonoids have also been shown to possess antimutagenic and antimalignant effect [39].

Qualitative HPLC analysis revealed that gallic acid and rutin are abundantly present in the different fractions of D. melanoxylon leaf extract. So $D$. melanoxylon leaf extract can be thought to be developed as a possible drug candidate.

After an extensive scan of available literature, it is noteworthy that widespread phenolic compounds such (-)-epigallocatechin-3gallate, caffeic acid, and chlorogenic acid can inhibit DNA methyltransferases and restore the expression of certain genes, which are silenced in cancer cells. Lee and Zhu (2006) demonstrated that caffeic acid or chlorogenic acid partially inhibited the methylation of promoter region of the RAR $\beta$ gene in breast cancer cells MCF7 and MDA-MB-231 [40, 41]. Yoshioka et al. (2000) also proved that flavonoids are responsible for inhibitory activity against cancerous cellines [42]. Aires et al. (2013) have demonstrated that phenolic compounds such as gallic acid and trans-resveratrol inhibited colon cancer cell growth through apoptosis induction [43]. These are some of the evidence which definitely give a strong indication of their involvement in the prevention and treatment of oxidative stressrelated diseases or disorders including cancer.

As a consequence, it is inferred from the above results that the flavonoid, phenolic, triterpenoid and tannin composition of different samples of the $D$. melanoxylon leaf extract are mainly responsible for their strong potency against different cancerous cell lines. For example, in this study, it was seen that two fractions namely EAF and AQE are more active against cancerous cell lines in a concentration-dependent manner. EAF have shown $\mathrm{IC}_{50}$ values of $41.52 \pm 1.4,51.59 \pm 0.85,83.68 \pm 4.08,75.18 \pm 1.83,122.77 \pm 3.7 ;$ and $\mathrm{AQF}$ showed $\mathrm{IC}_{50}$ values of $47.41 \pm 1.10,69.2 \pm 2.79,136.86 \pm 6.93$, $62.04 \pm 2.10$, and $161.59 \pm 2.15$ against cancerous cell lines of MCF-7, HCT116, PC-3, HEK293, RCC45, respectively.

Above results indicate the possible involvement of phenolics and flavonoids for the anticancer activity of EAF and AQF. This fact has already been generalized in the first half of the discussion portion. Moreover, this fact has also been duly supported in a review article which exemplifies a strong positive relation between phenolics/ flavonoids and anticancer activity [44]. CF and NHE did not show significant anticancer activity against all cancerous cell lines. According to Taylor et al. (2001), this can be accounted to the presence of insufficient quantities of the active principles in the $\mathrm{CF}$ and NHE and hence no activity was seen with the dose levels used [45].

A wide variety of methods have been used to determine the antioxidant activity of samples, and no single assay provides an accurate method for determining the capacity to scavenge free radicals. Therefore, it is essential to use diverse methods to assess different aspects of the oxidation process. Furthermore, different compounds may act as antioxidants through different mechanisms. Therefore, it has been recommended that at least two different assays should be used in evaluating the antioxidant activity of herbs [46]. Therefore, various samples were tested for their antioxidant 
potential using DPPH radical scavenging, hydroxyl radical scavenging, hydrogen peroxide scavenging, reducing power and the nitric oxide scavenging methods. All the four fractions so prepared were screened for in vitro antioxidant potential.

Phenolic compounds have been shown to be responsible for the antioxidant activity of plant materials [47]. However, in this case, results are interesting when it comes to formulate a relationship between total phenolic content and observed antioxidant activity for the EAF and AQF. These two fractions gave the highest yield of phenolics, flavonoids, triterpenoids, and tannins contents and also showed good anticancer action as evident from their low $\mathrm{IC}_{50}$ values. But when it comes to antioxidant potential, all fractions demonstrated significant high $\mathrm{IC}_{50}$ values of almost 5 times higher than the standard which was ascorbic acid. Higher phenolic content necessarily always does not indicate higher antioxidant potential. Many studies have focused on the biological activities of phenolics which are also potent antioxidants and free radical scavengers. The antioxidant activity of phenolics including flavonoids being mainly due to their redox properties, which allow them to act as reducing agents, hydrogen donors, and singlet oxygen quenchers [47]. The antioxidant activity of fractions could therefore not only be explained on the basis of their phenolic content but also required their proper characterization.

Furthermore, the samples are very complex mixtures of many different compounds with distinct activities. The lack of relationship observed in this study is in agreement with other report in the literature [48]. Sengul et al. (2009) also reported a negative correlation between total phenolic content and antioxidant capacities of a number of medicinal plants extracts [49]. Subethyl acetate fraction obtained from the plant D. melanoxylon Roxb. leaf and its polymeric nanoparticles showed significant anticancer activity against different cancerous cell lines [50]. Another polymeric nanoparticle prepared from the plant Anthocephalus cadamba containing chlorophyll fraction showed cytotoxicity activity in skin cancerous cell line [51].

The high $\mathrm{IC}_{50}$ values obtained in the active fraction of EAF and AQF probably indicates that oxidative mechanisms may not have been so predominant in the proliferation of cancer cells. The mechanism for the observed cytotoxic effects may probably be due to cell cycle arrest followed by apoptosis. Depicted results definitely question the commonly assumed involvement of the antioxidants in cancer treatment. Further committed studies are underway to elucidate the mechanisms involved. However, no doubts can be raised on the anticancer action of the plant D. melanoxylon. The fractions (EAF/AQE) which tested positively have a bright prospect to be developed as further drug candidates with high selectivity and efficacy.

The general consequences obtained from this study indicates that several fractions such as EAF and AQF of the plant D. melanoxylon have a bright prospective to be used as an anticancer agent.

\section{CONCLUSION}

This effort has gathered experimental confirmation that $D$. melanoxylon leaf fractions contained a significant amount of flavonoids, polyphenols, triterpenoids, and tannins. Moreover, it has been demonstrated that the D. melanoxylon leaf fractions are potential anticancer agents with minimal toxic effect on normal cell lines. The anticancer activity might be due to the presence of bioactive compounds in the plant. Additionally, this experiment indicated that the plant contained potential activities and seems to serve as a prospective material for the further development of novel plant-based anticancer mediators, which if properly and extensively studied, could provide many chemically interesting and biologically active drug candidates. The particularly anticancer activity of EAF and AQF justify deeper interest. Though, preparation of nanoparticles and meticulous investigation of their chemical composition and in vivo anticancer activity should be carried out in order to establish their potential realistic use.

\section{ACKNOWLEDGMENT}

We are grateful to "Innovation in Science Pursuit for Inspire Research" (INSPIRE) implemented by the Department of Science and
Technology (DST, Government of India, New Delhi, India) for financial support. The authors are also thankful to the authority of Jadavpur University and Bose Institute, Kolkata for affording necessary facilities.

\section{AUTHORS CONTRIBUTIONS}

Designed the experiments: Md Harun Al Rashid, Prof. S. C. Mandal, Dr. V. Mandal, Dr. M. Pal, Dr. A. T. Rajarajan. Performed the experiments: Md Harun Al Rashid, Deepak Bharadwaj PVP, Sayani Majumder. Wrote the paper: Md Harun Al Rashid. Revised the article critically for important intellectual content: Md Harun Al Rashid, Dr. V. Mandal.

\section{CONFLICT OF INTERESTS}

We declare that we have no conflict of interest

\section{REFERENCES}

1. Rajesh R, Chitra K, Paarakh PM, Chidambaranathan N. Anticancer activity of aerial parts of aerva lanata linn juss ex schult against dalton's ascitic lymphoma. Eur J Integr Med 2011 3:e245-e50.

2. Das M, Mohanty C, Sahoo SK. Ligand-based targeted therapy for cancer tissue. Expert Opin Drug Delivery 2009;6:285-304.

3. Sahoo S, Parveen S, Panda J. The present and future of nanotechnology in human health care. Nanomed Nanotechnol Biol Med 2007;3:20-31.

4. Mihailovic V, Misic D, Matic S, Mihailovic M, Stanic S, Vrvic MM, et al. Comparative phytochemical analysis of gentiana cruciata l. Roots and aerial parts, and their biological activities. Ind Crops Prod 2015;73:49-62.

5. Valko M, Leibfritz D, Moncol J, Cronin MT, Mazur M, Telser J. Free radicals and antioxidants in normal physiological functions and human disease. Int $\mathrm{J}$ Biochem Cell Biol 2007;39:44-84.

6. Wiseman $\mathrm{H}$, Halliwell B. Damage to DNA by reactive oxygen and nitrogen species: role in inflammatory disease and progression to cancer. Biochem J 1996;313:17.

7. Al Rashid MH, Mandal V, Mandal SRa SC. Herbal nanotechnology: an emerging tool in cancer therapy. Biology, Biotechnology, and Sustainable Development; 2015. p. 86.

8. Nurhanan M, Asiah O, Ilham MM, Syarifah MS, Norhayati I, Sahira HL. Anti-proliferative activities of 32 malaysian plant species in breast cancer cell lines. J Trop For Sci 2008;77-81.

9. Lo PC, Skeath JB, Gajewski K, Schulz RA, Frasch M. Homeotic genes autonomously specify the anteroposterior subdivision of the drosophila dorsal vessel into aorta and heart. Dev Biol 2002;251:307-19.

10. Raza H, John A. In vitro effects of tea polyphenols on redox metabolism, oxidative stress, and apoptosis in pc12 cells. Ann N Y Acad Sci 2008;1138:358-65.

11. Brewer M. Natural antioxidants: sources, compounds, mechanisms of action, and potential applications. Compr Rev Food Sci F 2011;10:221-47.

12. Dewick PM. Medicinal natural products: a biosynthetic approach. John Wiley and Sons; 2002.

13. Halliwell B, Gutteridge JM. Free radicals in biology and medicine. Oxford University Press, USA; 2015.

14. Aiyegoro OA, Okoh AI. Preliminary phytochemical screening and in vitro antioxidant activities of the aqueous extract of helichrysum longifolium dc. BMC Complement Altern Med 2010;10:21.

15. Mallavadhani U, Panda AK, Rao Y. Review article number 134 pharmacology and chemotaxonomy of diospyros. Phytochemistry 1998;49:901-51.

16. Chopea R. Poisonous plants of india. Poisonous plants of India; 1949.

17. Sastri B. The wealth of india. A dictionary of indian raw materials and industrial products. Raw materials. The Wealth of India A Dictionary of Indian Raw Materials and Industrial Products Raw Materials; 1950.

18. Banik R, Pandey D. Optimizing conditions for oleanolic acid extraction from lantana camara roots using response surface methodology. Ind Crops Prod 2008;27:241-8. 
19. Asaduzzaman M, Uddin MJ, Kader M, Alam A, Rahman AA, Rashid M, et al:: In vitro acetylcholinesterase, inhibitory activity and the antioxidant properties of aegle marmelos leaf extract: implications for the treatment of Alzheimer's disease. Psychogeriatrics 2014;14:1-10.

20. Ordonez A, Gomez J, Vattuone M. Antioxidant activities of sechium edule (jacq.) swartz extracts. Food Chem 2006; 97:452-8.

21. Fatiha B, Didier H, Naima G, Khodir M, Martin K, Léocadie K, et al. Phenolic composition, in vitro antioxidant effects and tyrosinase inhibitory activity of three algerian mentha species: M. Spicata (l.), m. Pulegium (l.) and m. Rotundifolia (l.) huds (lamiaceae). Ind Crops Prod 2015;74:722-30.

22. Koncic MZ, Kremer D, Gruz J, Strnad M, Bisevac G, Kosalec I, et al. Antioxidant and antimicrobial properties of moltkia petraea (tratt.) griseb. Flower, leaf and stem infusions. Food Chem Toxicol 2010;48:1537-42.

23. Fan JP, He CH. Simultaneous quantification of three major bioactive triterpene acids in the leaves of diospyros kaki by high-performance liquid chromatography method. J Pharm Biomed Anal 2006;41:950-6.

24. Russo D, Valentao P, Andrade PB, Fernandez EC, Milella L. Evaluation of antioxidant, antidiabetic and anticholinesterase activities of smallanthus sonchifolius landraces and correlation with their phytochemical profiles. Int J Mol Sci 2015;16:17696-718.

25. Singh R, Kumari N. Comparative determination of phytochemicals and antioxidant activity from leaf and fruit of sapindus mukorrossi gaertn.-a valuable medicinal tree. Ind Crops Prod 2015;73:1-8.

26. Sharma OP, Bhat TK. Dpph antioxidant assay revisited. Food Chem 2009;113:1202-5.

27. Ashraf A, Sarfraz RA, Mahmood A, ud Din M. Chemical composition and in vitro antioxidant and antitumor activities of eucalyptus camaldulensis dehn. Leaves Ind Crops Prod 2015;74:241-8.

28. Rao M. Nitric oxide scavenging by curcuminoids. J Pharm Pharmacol 1997;49:105-7.

29. Luqman S, Kumar R, Kaushik S, Srivastava S, Darokar MP, Khanuja SP. Antioxidant potential of the root of vetiveria zizanioides (l.) nash; 2009.

30. Irshad M, Zafaryab M, Singh M, Rizvi M. Comparative analysis of the antioxidant activity of cassia fistula extracts. Int J Med Chem 2012. http://dx.doi.org/10.1155/2012/157125

31. Khan RA, Khan MR, Sahreen S, Shah NA, Khan AM, Khan YM, et al. Effect of various fractions of launaea procumbens on antioxidant enzymes in rats liver: oxidative stress induced by potassium bromate (kbro3). Afr J Pharm Pharmacol 2012;6:512-5.

32. Rathore K, Singh VK, Jain P, Rao SP, Ahmed Z, Singh VD. In vitro and in vivo antiadipogenic, the hypolipidemic and antidiabetic activity of diospyros melanoxylon (roxb). J Ethnopharmacol 2014;155:1171-6.

33. Kedar P, Chakrabarti C. Effects of bittergourd (momordica charantia) seed and glibenclamide in streptozotocin induced diabetes mellitus. Indian J Exp Biol 1982;20:232.

34. Mandal V, Dewanjee S, Mandal SC. Microwave-assisted extraction of total bioactive saponin fraction from gymnema sylvestre with reference to gymnemagenin: a potential biomarker. Phytochem Anal: Int J Plant Chem Biochem Techniques 2009;20:491-7.

35. Yıldırım A, Mavi A, Kara AA. Determination of antioxidant and antimicrobial activities of rumex crispus l. Extracts. J Agric Food Chem 2001;49:4083-9.

36. Mandal V, Mandal SC. Design and performance evaluation of a microwave-based low carbon yielding extraction technique for naturally occurring bioactive triterpenoid: oleanolic acid. Biochem Eng J 2010;50:63-70.

37. Blois MS. Antioxidant determinations by the use of a stable free radical. Nature 1958;181:1199.

38. Bala A, Kar B, Haldar PK, Mazumder UK, Bera S. Evaluation of anticancer activity of cleome gynandra on ehrlich's ascites carcinoma treated mice. J Ethnopharmacol 2010;129:131-4.

39. Fotsis T, Pepper MS, Aktas E, Breit S, Rasku S, Adlercreutz H, et al. Flavonoids, dietary-derived inhibitors of cell proliferation and in vitro angiogenesis. Cancer Res 1997;57:2916-21.

40. Lee WJ, Zhu BT. Inhibition of DNA methylation by caffeic acid and chlorogenic acid, two common catechol-containing coffee polyphenols. Carcinogenesis 2005;27:269-77.

41. Lee WJ, Shim JY, Zhu BT. Mechanisms for the inhibition of DNA methyltransferases by tea catechins and bioflavonoids. Mol Pharmacol; 2005.

42. Yoshioka K, Kataoka T, Hayashi T, Hasegawa M, Ishi $\mathrm{Y}$, Hibasami H. Induction of apoptosis by gallic acid in human stomach cancer kato iii and colon adenocarcinoma colo 205 cell lines. Oncol Rep 2000;7:1221-4.

43. Aires V, Limagne E, Cotte AK, Latruffe N, Ghiringhelli F, Delmas D. Resveratrol metabolites inhibit human metastatic colon cancer cells progression and synergize with chemotherapeutic drugs to induce cell death. Mol Nutr Food Res 2013;57:117081.

44. Roleira FM, Tavares-da-silva EJ, Varela CL, Costa SC, Silva T, Garrido J, et al. Plant-derived and dietary phenolic antioxidants: anticancer properties. Food Chem 2015;183:235-58.

45. Taylor J, Rabe T, McGaw L, Jäger A, Van Staden J. Towards the scientific validation of traditional medicinal plants. Plant Growth Regul 2001;34:23-37.

46. Moon JK, Shibamoto T. Antioxidant assays for plant and food components. J Agric Food Chem 2009;57:1655-66.

47. Rice Evans CA, Miller NJ, Paganga G. Structure-antioxidant activity relationships of flavonoids and phenolic acids. Free Radical Biol Med 1996;20:933-56.

48. Ghasemi K, Ghasemi Y, Ebrahimzadeh MA. Antioxidant activity, phenol and flavonoid contents of 13 citrus species peels and tissues. Pak J Pharm Sci 2009;22:277-81.

49. Sengul M, Yildiz H, Gungor N, Cetin B, Eser Z, Ercisli S. Total phenolic content, antioxidant and antimicrobial activities of some medicinal plants. Pak J Pharm Sci 2009;22:102-6.

50. Al Rashid H. Preparation and characterization of plga loaded nanoparticles obtained from d. Melanoxylon roxb. Leaves for their antiproliferative and antidiabetic activity. Int J Green Pharm 2017;11:S438-S447.

51. Pemmaraju D, Appidi T, Minhas G, Singh SP, Khan N, Pal M, et al. Chlorophyll rich biomolecular fraction of a. Cadamba loaded into polymeric nanosystem coupled with photothermal therapy: a synergistic approach for cancer theranostics. Int J Biol Macromol 2018;110:383-91. 